Article

\title{
Oleodaphnoic Acid and Coriaceol, Two New Natural Products from the Stem Bark of Wikstroemia coriacea
}

\author{
Nicolas Ingert ${ }^{1,2}$, Isabelle Bombarda ${ }^{3}$, Gaëtan Herbette ${ }^{4}$, Robert Faure ${ }^{5}$, Christian Moretti ${ }^{2}$ \\ and Phila Raharivelomanana ${ }^{1, *}$
}

1 EIMS, UMR 241 Ecosystèmes Insulaires Océaniens Université de la Polynésie Française, Tahiti 98702 FAA’A, French Polynesia

2 Centre Polynésien de Recherche sur la Biodiversité Insulaire, UMR 7138, IRD, Papeete BP 529-98713, French Polynesia

3 LISA EA 4672, Aix-Marseille Université, Campus de St Jérôme, Marseille 13397, cedex 20, France

4 Spectropole, FR1739, Aix-Marseille Université, Campus de St Jérôme - service 511, Marseille 13397, cedex 20, France

5 SMBSO, UMR 7273, ICR, Aix-Marseille Université, Campus de St Jérôme - service 522, Marseille 13397, cedex 20, France

* Author to whom correspondence should be addressed; E-Mail: phila.raharivelomanana@upf.pf; Tel.: +689-803-813; Fax: +689-803-804.

Received: 10 December 2012; in revised form: 25 February 2013 / Accepted: 28 February 2013 / Published: 5 March 2013

\begin{abstract}
Fractionation of the chloroform extract of Wikstroemia coriacea led to the isolation of two new compounds, oleodaphnoic acid (1), a guaiane-type sesquiterpenoid, and coriaceol (2), an 1,5-diphenyl-1-pentanone analogue, together with nine known compounds. The structures of $\mathbf{1}$ and $\mathbf{2}$ were elucidated by extensive spectroscopic data analysis. The known compounds were oleodaphnal (3), indicanone (4), $(5 R, 8 R, 8 \mathrm{a} R)-3,8$ dimethyl-4,5,6,7,8,8a-hexahydro-5-(1-methylethenyl)-2(1H)-azulenone, (5), 1,5 diphenyl-1pentanone (6), (+)-3-hydroxy-1,5-diphenyl-1-pentanone (7), umbelliferone (8), daphnoretin (9), $\beta$-sitostenone (10) and (-)-hinokinin (11).
\end{abstract}

Keywords: oleodaphnoic acid; coriaceol; Wikstroemia coriaceae; Thymelaeaceae; guaiane; 1,5-diphenyl-1-pentanone 


\section{Introduction}

Wikstroemia (Thymelaeaceae) is a genus consisting of about 70 species indigenous to Asia, Malaysia, Australia and Pacific Islands [1]. Wikstroemia coriacea B.C. Seemann [2] is an endemic plant, widely distributed in Eastern Polynesia, which is used in folk medicine for its emetic, purgative, narcotic and vesicant properties [3]. Moreover, leaves and stems were used for the treatment of syphilis, gonorrhea, urethritis and leucorrhea [4]. Although there are many phytochemical reports on the genus Wikstroemia focused on sesquiterpenes [5,6], diterpenes [7-10], triterpenes [7,11], coumarins [12-14], flavonoids [15-17] and lignans [7,18-20], no study has been carried out on the chemistry of Wikstroemia coriacea. This paper reports our phytochemical discovery of two new natural compounds, oleodaphnoic acid (1), a guaiane-type sesquiterpenoid, and coriaceol (2), an 1,5-diphenyl-1-pentanone (6) analogue, along with nine known compounds including oleodaphnal (3), indicanone (4), (5R,8R,8aR)-3,8-dimethyl-4,5,6,7,8,8a-hexahydro-5-(1-methylethenyl)-2(1H)-azulenone, (5), 1,5-diphenyl-1-pentanone (6), (+)-3-hydroxy-1,5-diphenyl-1-pentanone (7), umbelliferone (8), daphnoretin (9), $\beta$-sitostenone (10) and (-)-hinokinin (11) (Figure 1). In addition, (-)-hinokinin (11) was isolated for the first time in the genus Wikstroemia.

Figure 1. Chemical structures of compounds 1-11.

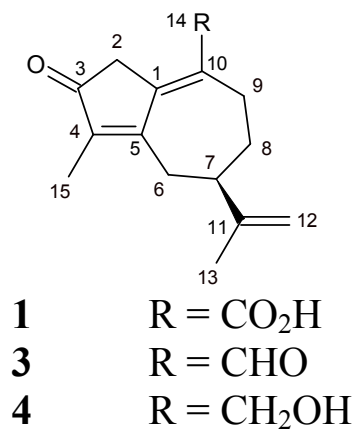<smiles>O=c1ccc2ccc(O)cc2o1</smiles>

8<smiles>COc1cc2cc(Oc3ccc4ccc(=O)oc4c3)c(=O)oc2cc1O</smiles>

9

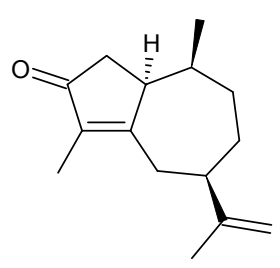

5

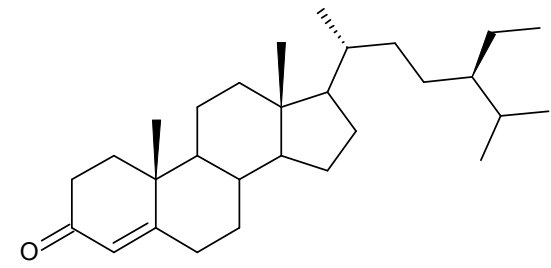

10

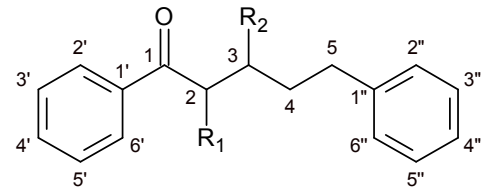

$2 \quad \mathrm{R}_{1}=\mathrm{OH} ; \mathrm{R}_{2}=\mathrm{H}$

$6 \quad \mathrm{R}_{1}=\mathrm{R}_{2}=\mathrm{H}$

$7 \quad \mathrm{R}_{1}=\mathrm{H} ; \mathrm{R}_{2}=\mathrm{OH}(\mathrm{S})$

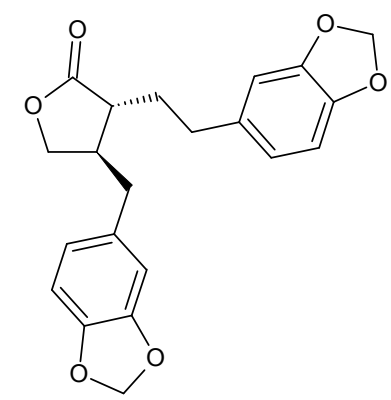

11

\section{Results and Discussion}

A total of eleven compounds were identified from the stem bark of $W$. coriacea. A new sesquiterpenoid oleodaphnoic acid (1, Figure 1) was isolated as a colorless powder. Its molecular formula $\mathrm{C}_{15} \mathrm{H}_{18} \mathrm{O}_{3}$ was assigned on the basis of HR-ESI-MS ( $m / z 247.1326[\mathrm{M}+\mathrm{H}]^{+}$, calcd. 247.1329), implying seven degrees of unsaturation. The IR spectrum displayed significant bands for an unsaturated ketone $\left(1681 \mathrm{~cm}^{-1}\right)$ and an $\alpha, \beta, \gamma, \delta$ unsaturated carboxylic acid $\left(3373\right.$ and $\left.1646 \mathrm{~cm}^{-1}\right)$. The 
${ }^{1}$ H-NMR spectrum showed two tertiary methyl groups as singlets ( $\delta 1.85$ and 1.77$)$, and an exo-methylene resonance as two broad singlets ( $\delta 4.76$ and 4.75) (Table 1$)$. The ${ }^{13} \mathrm{C}$-DEPTQ NMR spectrum exhibited 15 carbon resonances, including two methyls, four methylenes, one exo-methylene, one ketone, one carboxylic function and two double bonds (Table 1). From the COSY and HSQC spectra, the occurrence of both partial structures, $\mathrm{CH}_{3} \mathrm{C}=\mathrm{CH}_{2}$ and $\mathrm{CH}_{2} \mathrm{CH}_{2} \mathrm{CHCH}_{2}$, was suggested. In the HMBC diagram, cross-peak observed between the methyl protons $\mathrm{H}-13$ and the methine carbon $\mathrm{C}-7$ was indicative of the combination of the above partial structures. Further analysis of the other significant long-range ${ }^{1} \mathrm{H}-{ }^{13} \mathrm{C}$ correlations (Figure 2) suggested that NMR data were typical of a guaiane-type skeleton [21]. NMR data close similarity regarding the C-7 carbons of oleodaphnal (3) [22], indicanone (4) [6] and $(5 R, 8 R, 8 \mathrm{a} R)$-3,8-dimethyl-4,5,6,7,8,8a-hexahydro-5-(1-methylethenyl)-2(1H)-azulenone (5) [23], respectively, allowed to infer the $R$ stereochemistry of C-7. Finally, the carboxylic group was assigned to be at the C-10 position based on the HMBC relationship between H-9 and C-14. From the above results the structure of oleodaphnoic acid was formulated as $\mathbf{1}$.

Table 1. ${ }^{1} \mathrm{H}-\mathrm{NMR}\left(500 \mathrm{MHz}\right.$,) and ${ }^{13} \mathrm{C}-\mathrm{NMR}(125 \mathrm{MHz}$,) data of oleodaphnoic acid (1) $\left(\mathrm{CDCl}_{3}\right)$ and coriaceol (2) $\left(\mathrm{CD}_{3} \mathrm{OD}\right)$.

\begin{tabular}{|c|c|c|c|c|c|}
\hline \multirow{2}{*}{ Position } & \multicolumn{2}{|l|}{1} & \multirow{2}{*}{ Position } & \multicolumn{2}{|l|}{2} \\
\hline & ${ }^{1} \mathbf{H}(\delta)$ & ${ }^{13} \mathrm{C}(\delta)$ & & ${ }^{1} \mathrm{H}(\delta)$ & ${ }^{13} \mathrm{C}(\delta)$ \\
\hline 1 & - & 149.5 & 1 & - & 203.2 \\
\hline 2 & $3.38(\mathrm{brs}, 2 \mathrm{H})$ & 42.2 & 2 & $5.10(\mathrm{dd}, 8.4 ; 3.3,1 \mathrm{H})$ & 74.1 \\
\hline 3 & - & 204.6 & 3 & $1.83(\mathrm{~m}, 1 \mathrm{H})$ & 35.4 \\
\hline 4 & - & 144.7 & & $1.59(\mathrm{~m}, 1 \mathrm{H})$ & \\
\hline 5 & - & 166.1 & 4 & $1.83(\mathrm{~m}, 1 \mathrm{H})$ & 27.9 \\
\hline 6 & $2.81(\mathrm{~m}, 2 \mathrm{H})$ & 32.1 & & $1.74(\mathrm{~m}, 1 \mathrm{H})$ & \\
\hline 7 & 2.54 (quint, $7.3,1 \mathrm{H}$ ) & 42.5 & 5 & $2.65(\mathrm{dt}, 14.0 ; 7.3,1 \mathrm{H})$ & 36.3 \\
\hline \multirow[t]{2}{*}{8} & $2.01(\mathrm{~m}, 1 \mathrm{H})$ & 32.0 & & $2.60(\mathrm{dt}, 14.0 ; 7.3,1 \mathrm{H})$ & \\
\hline & $1.81(\mathrm{~m}, 1 \mathrm{H})$ & & $1^{\prime}$ & - & 136.0 \\
\hline 9 & $2.80(\mathrm{~m}, 2 \mathrm{H})$ & 25.6 & $2^{\prime}, 6^{\prime}$ & $7.90(\mathrm{~m}, 2 \mathrm{H})$ & 129.5 \\
\hline 10 & - & 127.7 & $3^{\prime}, 5^{\prime}$ & $7.48(\mathrm{~m}, 2 \mathrm{H})$ & 129.9 \\
\hline 11 & - & 148.7 & 4' & $7.61(\mathrm{~m}, 1 \mathrm{H})$ & 134.6 \\
\hline \multirow[t]{2}{*}{12} & $4.76(\mathrm{brs}, 1 \mathrm{H})$ & 110.1 & $1 "$ & - & 143.2 \\
\hline & $4.75(\mathrm{brs}, 1 \mathrm{H})$ & & 2", 6" & $7.13(\mathrm{~m}, 2 \mathrm{H})$ & 129.3 \\
\hline 13 & $1.77(\mathrm{~s}, 3 \mathrm{H})$ & 20.9 & 3", 5" & $7.22(\mathrm{~m}, 2 \mathrm{H})$ & 129.4 \\
\hline 14 & - & 172.7 & 4" & $7.13(\mathrm{~m}, 1 \mathrm{H})$ & 126.8 \\
\hline 15 & $1.85(\mathrm{~s}, 3 \mathrm{H})$ & 9.0 & & & \\
\hline
\end{tabular}

Figure 2. Key HMBC Correlations $(\mathrm{H} \rightarrow \mathrm{C})$ of oleodaphnoic acid (1).

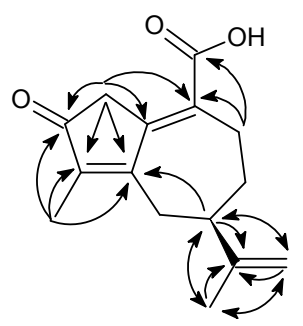

A new natural phenylphenalenone named coriaceol (2, Figure 1) was obtained as an yellowish oil and showed an accurate $[\mathrm{M}+\mathrm{H}]^{+}$ion at $\mathrm{m} / z$ 255.1381 (calcd. 255,1379) in the HR-ESI-MS corresponding to the empirical molecular formula $\mathrm{C}_{17} \mathrm{H}_{18} \mathrm{O}_{2}$ and implying nine degrees of unsaturation. 
The IR spectrum of 2 suggested the presence of hydroxyl group $\left(3440 \mathrm{~cm}^{-1}\right)$, conjugated ketone carbonyl $\left(1683 \mathrm{~cm}^{-1}\right)$ and aromatic rings $\left(1603-1480 \mathrm{~cm}^{-1}\right)$. The ${ }^{13} \mathrm{C}-\mathrm{NMR}$ spectrum gave a total of 17 separate resonances and the ${ }^{13} \mathrm{C}$-DEPTQ sequence showed three methylene, eleven methine groups and three quaternary carbons, including a conjugated ketone carbonyl at $\delta 203.2$ (Table 1). The ${ }^{1} \mathrm{H}-\mathrm{NMR}$ spectrum exhibited two AA'MM'X spin systems, typical of two monosubstituted aromatic rings and an oxygen-bearing methine signal at $\delta 5.10(\mathrm{dd}, J=8.4,3.3 \mathrm{~Hz}$ ) (Table 1). With the aid of COSY experiments, a - $\mathrm{OCH}\left(\mathrm{CH}_{2}\right)_{3}$ subunit was identified by further analysis of the remaining ${ }^{1} \mathrm{H}$ resonances. Finally, the location of the two phenyl moieties was supported by the HMBC correlations observed between the ortho $\mathrm{H}-2^{\prime}$ (d 7.90) and H-2" (d 7.13) signals and carbons $\mathrm{C}-1$ and $\mathrm{CH}_{2}-5$, respectively. From the above spectral data, the structure of coriaceol (2) was established as 2-hydroxy-1,5diphenylpentan-1-one. This compound, which was previously reported with no NMR data as a synthetic intermediate [24], had not yet previously isolated from a natural source. Attempt to determine the stereochemistry at C-2 was not successful due to the decomposition of the compound.

In addition to these two new structures, we isolated three sesquiterpenoids: oleodaphnal (3) [22], indicanone (4) [6], $(5 R, 8 R, 8 \mathrm{a} R)-3,8$-dimethyl-4,5,6,7,8,8a-hexahydro-5-(1-methylethenyl)-2(1H)azulenone, (5) [23]; two phenylphenalenones: 1,5-diphenyl-1-pentanone (6) [25], (+)-3-hydroxy-1,5diphenyl-1-pentanone (7) [26]; two coumarins: umbelliferone (8) [27], daphnoretin (9) [28]; one triterpenoid: $\beta$-sitostenone (10) [29] and one lignan: (-)-hinokinin (11) [30] (Figure 1). The identifications of these nine known compounds were confirmed by comparison of their physical and spectroscopic data (UV, ${ }^{1} \mathrm{H},{ }^{13} \mathrm{C}-\mathrm{NMR}, \mathrm{MS}$ and $[\alpha]$ ) with the corresponding authentic samples or with values described in the literature.

Literature data reported that most of the isolated compounds are known to possess interesting biological activities such as: indicanone (4) for its anti-inflammatory activity [6]; (5R,8R,8aR)-3,8dimethyl-4,5,6,7,8,8a-hexahydro-5-(1-methylethenyl)-2(1H)-azulenone (5) for its cytotoxic activity on the P-388 cell line [5,31]; (+)-3-hydroxy-1,5-diphenyl-1-pentanone (7) for its anti-HIV activity [26]; umbelliferone (8) for its anti-inflammatory activities [27], antioxidant [32,33], antihyperlipidemic [34] and anticancer [35-37], daphnoretin (9) for its antifungal [38], anticancer [15], inhibition of various sites in DNA synthesized voice [14], activation of protein kinase C (platelet aggregation) [39,40], antiviral hepatitis B [41] and respiratory syncytial virus (RSV) properties [42]; the triterpenoid $\beta$-sitostenone (10) for its interesting biological activities as a strong hypoglycemic [43] and antiarrhythmic [44,45], anti-emetic [46], vasodilator agent [47], and also for its antituberculosis activity [45,48] and anti-inflammatory activity [49]; (-)-hinokinine for its antiparasitic, antifungal [50], antigenotoxic and antioxidant activities [30].

\section{Experimental}

\subsection{General}

HPLC was performed using an Agilent 1100 pump equipped with a Varian Dynamax Microsorb Si column $(250 \times 21.4 \mathrm{~mm}$ i.d., $5 \mu \mathrm{m}, 100 \AA)$ and a Varian Dynamax Microsorb C18 column $(250 \times 10 \mathrm{~mm}$ i.d., $5 \mu \mathrm{m}, 100 \AA$ ), respectively, a refractomeric and a Diode Array Detector (DAD) detector. Optical rotations were measured on a Perkin-Elmer model 241 polarimeter equipped with a sodium lamp 
$(589 \mathrm{~nm})$ and a $1 \mathrm{dm}$ cell. HRMS experiments were performed with a QStar Elite mass spectrometer (Applied Biosystems SCIEX) equipped with an ESI source operated in the positive ion mode. IR spectra were obtained with cell composed of two calcium fluoride windows separated by $0.21-\mathrm{mm}$ thick PTFE spacer A145 using a Bruker FTIR Vertex 70 spectrometer. NMR spectra were recorded at $300 \mathrm{~K}$ for $\sim 1 \mathrm{mg}$ samples using a Bruker Avance DRX 500 spectrometer, equipped with a Bruker Cryoplateform and a $5 \mathrm{~mm}$ TXI cryoprobe. NMR spectra were referenced to $\mathrm{CDCl}_{3}\left(\delta_{\mathrm{H}}=7.26 \mathrm{ppm}\right.$ and $\left.\delta_{\mathrm{C}}=77.16 \mathrm{ppm}\right)$ or to $\mathrm{CD}_{3} \mathrm{OD}\left(\delta_{\mathrm{H}}=3.31 \mathrm{ppm}\right.$ and $\left.\delta_{\mathrm{C}}=49.00 \mathrm{ppm}\right)$ [51]. Standard Bruker pulse sequences were used for homonuclear and heteronuclear two-dimensional experiments.

\subsection{Plant Material}

The stem bark of $W$. coriacea was collected from Nuku Hiva, Marquesas Islands, and was identified by Dr Jean-François Butaud. A voucher specimen (CM 1725) has been deposited in the Herbarium of French Polynesia [52].

\subsection{Extraction and Isolation}

Air-dried and powdered stem bark of $W$. coriacea $(150 \mathrm{~g})$ was extracted with chloroform $(3 \times 350 \mathrm{~mL}$, 3h rt.) for $10 \mathrm{~h}$. After concentration in vacuo, the remaining solid $(7.75 \mathrm{~g})$ was subjected to low pressure chromatography $\left(\mathrm{SiO}_{2} ; \mathrm{CHCl}_{3} / \mathrm{MeOH}, 1: 0\right.$ to $9: 1, \mathrm{v}: \mathrm{v}$, then $\left.\mathrm{MeOH}\right)$ to yield three fractions $F_{1}(3.2 \mathrm{~g}), F_{2}(2.8 \mathrm{~g})$ and $F_{3}(1.5 \mathrm{~g}) . F_{1}(79 \mathrm{mg})$ was chromatographed by semi-preparative HPLC $\left(\mathrm{SiO}_{2}\right.$; hexane/isopropanol, 99:1, v:v, $\left.10 \mathrm{~mL} / \mathrm{min}\right)$ to provide oleodaphnal (3, $\left.4.4 \mathrm{mg}\right)$, (5R,8R,8aR)-3,8-dimethyl-4,5,6,7,8,8a-hexahydro-5-(1-methylethenyl)-2(1H)-azulenone, (5, $4.5 \mathrm{mg})$, 1,5-diphenyl-1-pentanone (6, $4.6 \mathrm{mg}), \quad$-hydroxy-1,5-diphenyl-1-pentanone $(2,2.8 \mathrm{mg})$, and (+)-3-hydroxy-1,5-diphenyl-1-pentanone (7, $1.9 \mathrm{mg}), \beta$-sitostenone (10, $1 \mathrm{mg})$ and (-)-hinokinin $(\mathbf{1 1}, 0.6 \mathrm{mg}) . \mathrm{F}_{2}(1.34 \mathrm{~g})$ was fractioned using $\mathrm{LH} 20\left(\mathrm{CH}_{2} \mathrm{Cl}_{2} / \mathrm{MeOH}, 1: 1\right.$, v:v) to isolate umbelliferone $(8,68 \mathrm{mg})$, daphnoretin $(\mathbf{9}, 40 \mathrm{mg})$ and indicanone $(4,7.7 \mathrm{mg})$. Oleodaphnoic acid $(\mathbf{1}, 11 \mathrm{mg})$ was obtained from $\mathrm{F}_{3}(108 \mathrm{mg})$ through semi-preparative HPLC $\left(\mathrm{C} 18 ; \mathrm{H}_{2} \mathrm{O} / \mathrm{EtOH}, 7: 3\right.$ to $0: 1$ for $30 \mathrm{~min}$ then $0: 110 \mathrm{~min}, \mathrm{v}: \mathrm{v}, 2.3 \mathrm{~mL} / \mathrm{min})$.

Oleodaphnoic acid (1). Colorless powder; $\mathrm{C}_{15} \mathrm{H}_{18} \mathrm{O}_{3} ;[\alpha]_{D}^{25}+8$ (c $0.02 \mathrm{CHCl}_{3}$ ); HR-ESI-MS $\mathrm{m} / \mathrm{z}$ 247.1326 [M+H] $]^{+}$, calcd. 247.1329; FTIR $\left(\mathrm{CCl}_{4}\right) v_{\max } 3373,1681,1646,1599,1516,1448,1384 \mathrm{~cm}^{-1}$; ${ }^{1} \mathrm{H}$ - and ${ }^{13} \mathrm{C}-\mathrm{NMR}\left(\mathrm{CDCl}_{3}\right)$ data, see Table 1.

Coriaceol (2). Yellowish oil; $\mathrm{C}_{17} \mathrm{H}_{18} \mathrm{O}_{2} ;[\alpha]_{D}^{25}-12$ (c $0.003 \mathrm{MeOH}$ ); HR-ESI-MS $m / z$ 255.1381 [M+H] calcd. 255.1379; FTIR $\left(\mathrm{CCl}_{4}\right) \mathrm{v}_{\max } 3440,1683,1646,1593,1578,1490,1362 \mathrm{~cm}^{-1}$; ${ }^{1} \mathrm{H}-$ and ${ }^{13} \mathrm{C}-\mathrm{NMR}$ $\left(\mathrm{CD}_{3} \mathrm{OD}\right)$ data, see Table 1 .

\section{Conclusions}

This work is part of our ongoing phytochemical studies on Polynesian endemic plants aiming at a better knowledge of Polynesian plant biodiversity. We report herein the first phytochemical assessment of the stem bark of $W$. coriacea with the occurrence of two new natural compounds oleodaphnoic acid (1) and and coriaceol (2), a 1,5-diphenyl-1-pentanone analogue, beside nine known 
ones. The identified components belong to different secondary metabolite classes including guaiane-type sesquiterpenoids (compounds $\mathbf{1}, \mathbf{3}, \mathbf{4}, \mathbf{5})$, triterpenoids $(\mathbf{1 0})$, phenylphenalenones $(\mathbf{2}, \mathbf{6}, \mathbf{7})$, coumarins $(\mathbf{8}, \mathbf{9})$ and a lignan $(\mathbf{1 1})$ which raises questions about the complexity of the biosynthetic routes to yield such less common chemodiversity exhibited by the same plant. Most of the isolated compounds are known for their relevant biological activities, which add more interest to this endemic Polynesian plant. We will follow up phytochemical analysis along with phylogenetic studies of all endemic species belonging to Wikstroemia genus grown in Polynesia aiming at a biodiversity assessment regarding insular plant adaptation and evolution.

\section{Acknowledgments}

The authors are thankful to the "Ministère de l'Enseignement, de la Recherche et de la Technologie" of France for N. Ingert PhD Grant, to the "Délégation à la Recherche de la Polynésie Française" for financial support (Marquesas Research program), and to J.F. Butaud for botanical identification and plant localisation.

\section{References}

1. Wang, Y.; Gilbert, M.G. WIKSTROEMIA Endlicher, Prodr. Fl. Norfolk. In Flora of China; Science Press and Missouri Botanical Garden: Beijing, China and St. Louis, MO, USA, 2007; Volume 13, pp. 215-229.

2. Butaud, J.-F.; Cartier, C.L.; Florence, J.; Perlman, S.P.; Sachet, M.-H.; Wood, K.R. Herbier de la Polynésie française: Wikstroemia coriacea B.C. Seemann. Available online: http://www. herbier-tahiti.pf/Selection_Taxonomie.php?id_tax=10079/(accessed on 26 November 2012).

3. Pétard, P. Plantes utiles de la Polynésie-Raau Tahiti; Haere Po No Tahiti: Papeete, French Polynesia, 1986.

4. Nadeaud, J. Plantes usuelles des Tahitiens; J. Martel: Montpellier, French Polynesia, 1864.

5. Lin, R.-W.; Tsai, I.-L.; Duh, C.-Y.; Lee, K.-H.; Chen, I.-S. New Lignans and Cytotoxic Constituents from Wikstroemia lanceolata. Planta Med. 2004, 70, 234-238.

6. Wang, L.Y.; Unehara, T.; Kitanaka, S. Anti-inflammatory activity of new guaiane type sesquiterpene from Wikstroemia indica. Chem. Pharm. Bull. 2005, 53, 137-139.

7. Borris, R.P.; Blaskó, G.; Cordell, G.A. Ethnopharmacologic and phytochemical studies of the Thymelaeaceae. J. Ethnopharmacol. 1988, 24, 41-91.

8. Wu, D.; Sorg, B.; Adolf, W.; Opferkuch, H.J.; Seip, E.H.; Hecker, E. Oligo- and macrocyclic diterpenes in thymelaeaceae and euphorbiaceae occurring and utilized in yunnan (Southwest China) 4. Tigliane type diterpene esters (phorbol-12,13-diesters) from Wikstroemia canescens. Phytother. Res. 1993, 7, 194-196.

9. Abe, F.; Iwase, Y.; Yamauchi, T.; Kinjo, K.; Yaga, S.; Ishii, M.; Iwahana, M. Minor daphnane-type diterpenoids from Wikstroemia retusa. Phytochemistry 1998, 47, 833-837.

10. Abe, F.; Iwase, Y.; Yamauchi, T.; Kinjo, K.; Yaga, S. Daphnane diterpenoids from the bark of Wikstroemia retusa. Phytochemistry 1997, 44, 643-647.

11. Chen, C.C.; Lin, Y.C.; Chen, Y.P.; Hsu, H.Y. A study on the constituents of Wikstroemia indica. Taiwan Yao Hsueh Tsa Chih 1981, 33, 28-29. 
12. Nakabayashi, T. Studies on the coumarin derivatives. VII. Constituents of the bark of Daphne Kiusiana Miquel and others (Thymelaeaceae). J. Pharm. Biomed. Anal. 1954, 74, 192-194.

13. Tandon, S.; Rastogi, R.P. Wikstrosin, a tricoumarin from Wikstroemia viridiflora. Phytochemistry 1977, 16, 1991-1993.

14. Hall, I.H.; Tagahara, K.; Lee, K.H. Antitumor agents LIII: The effects of daphnoretin on nucleic acid and protein synthesis of ehrlich ascites tumor cells. J. Pharm. Sci. 1982, 71, 741-744.

15. Lee, K.-H.; Tagahara, K.; Suzuki, H.; Wu, R.-Y.; Haruna, M.; Hall, I.H.; Huang, H.-C.; Ito, K.; Iida, T.; Lai, J.-S. Antitumor Agents. 49. Tricin,Kaempferol-3-O- $\beta$-D-Glucopyranoside and (+)-Nortrachelogenin, Antileukemic Principles From Wikstroemia indica. J. Nat. Prod. 1981, 44, 530-535.

16. Niwa, M.; Jiang, P.-F.; Hirata, Y. Two New C-3/C-3"-Biflavanones from Wikstroemia sikokiana. Chem. Pharm. Bull. 1986, 34, 3631-3634.

17. Baba, K.; Taniguchi, M.; Kozawa, M. Three biflavonoids from Wikstroemia sikokiana. Phytochemistry 1994, 37, 879-883.

18. Tandon, S.; Rastogi, R.P. Wikstromol, a new lignan from Wikstroemia viridiflora. Phytochemistry 1976, 15, 1789-1791.

19. Torrance, S.J.; Hoffmann, J.J.; Cole, J.R. Wikstromol, antitumor lignan from Wikstroemia foetida var. oahuensis gray and Wikstroemia uva-ursi gray (thymelaeaceae). J. Pharm. Sci. 1979, 68, $664-665$.

20. Suzuki, H.; Lee, K.-H.; Haruna, M.; Iida, T.; Ito, K.; Huang, H.-C. (+)-Arctigenin, a lignan from Wikstroemia indica. Phytochemistry 1982, 21, 1824-1825.

21. Rahman, A.-U.; Ahmad, V.U. 13C-NMR of Natural Products; Plenum Publishing: New York, NY, USA, 1992; Volume 1, p. 984.

22. Taninaka, H.; Takaishi, Y.; Honda, G.; Imakura, Y.; Sezik, E.; Yesilada, E. Terpenoids and aromatic compounds from Daphne oleoides ssp. oleoides. Phytochemistry 1999, 52, 1525-1529.

23. Zdero, C.; Bohlmann, F.; Niemeyer, H.M. Isocedrene and Guaiane Derivatives from Pleocarphus revolutus. J. Nat. Prod. 1988, 51, 509-512.

24. Vitale, A.A.; Doctorovich, F.; Sbarbati Nudelman, N. One-pot synthesis of diarylalkylcarbinols and substituted derivatives through carbon monoxide insertion reactions into aryllithiums. J. Organomet. Chem. 1987, 332, 9-18.

25. Martínez, R.; Ramón, D.J.; Yus, M. Easy $\alpha$-alkylation of ketones with alcohols through a hydrogen autotransfer process catalyzed by $\mathrm{RuCl}_{2}(\mathrm{DMSO})_{4}$. Tetrahedron 2006, 62, 8988-9001.

26. Huang, S.Z.; Zhang, X.J.; Li, X.Y.; Jiang, H.Z.; Ma, Q.Y.; Wang, P.C.; Liu, Y.Q.; Hu, J.M.; Zheng, Y.T.; Zhou, J.; et al. Phenols with Anti-HIV Activity from Daphne acutiloba. Planta Med. 2012, 78, 182-185.

27. Kim, J.S.; Kim, J.C.; Shim, S.H.; Lee, E.J.; Jin, W.; Bae, K.; Son, K.H.; Kim, H.P.; Kang, S.S.; Chang, H.W. Chemical constituents of the root of Dystaenia takeshimana and their anti-inflammatory activity. Arch. Pharm. Res. 2006, 29, 617-623.

28. Navarro-Garcia, V.M.; Herrera-Ruiz, M.; Rojas, G.; Zepeda, L.G. Coumarin derivatives from Loeselia mexicana. Determination of the anxiolytic effect of daphnoretin on elevated plus-maze. J. Mex. Chem. Soc. 2007, 51, 193-197. 
29. Seca, A.M.L.; Silva, A.M.S.; Silvestre, A.J.D.; Cavaleiro, J.A.S.; Domingues, F.M.J.; Neto, C.P. Chemical composition of the light petroleum extract of Hibiscus cannabinus bark and core. Phytochem. Anal. 2000, 11, 345-350.

30. Medola, J.F.; Cintra, V.P.; Pesqueira e Silva, É.P.C.; de Andrade Royo, V.; da Silva, R.; Saraiva, J.; Albuquerque, S.; Bastos, J.K.; Andrade e Silva, M.L.; Tavares, D.C. (-)-Hinokinin causes antigenotoxicity but not genotoxicity in peripheral blood of Wistar rats. Food Chem. Toxicol. 2007, 45, 638-642.

31. Blay, G.; Garcia, B.; Molina, E.; Pedro, J.R. Synthesis of all 7[alpha]H-guaia-4,11-dien-3-one diastereomers from (+)-dihydrocarvone. Tetrahedron 2005, 61, 11156-11162.

32. Hoult, J.R.S.; Payá, M. Pharmacological and biochemical actions of simple coumarins: Natural products with therapeutic potential. Gen. Pharmacol. 1996, 27, 713-722.

33. Singh, R.; Singh, B.; Singh, S.; Kumar, N.; Kumar, S.; Arora, S. Umbelliferone-An antioxidant isolated from Acacia nilotica (L.) Willd. Ex. Del. Food Chem. 2010, 120, 825-830.

34. Ramesh, B.; Pugalendi, K.V. Antihyperglycemic effect of Umbelliferone in streptozotocin-diabetic rats. J. Med. Food 2006, 9, 562-566.

35. Sharifi, S.; Lotterer, E.; Michaelis, H.C.; Bircher, J. Pharmaco-kinetics of coumarin and its metabolites. Preliminary results in three healthy volunteers. J. Irish Coll. Phys. Surg. 1992, 22, 29-32.

36. Marshall, M.E.; Kervin, K.; Benefield, C.; Umerani, A.; Albainyjenei, S.; Zhao, Q.; Khazaeli, M.B. Growth-inhibitory effects of coumarin (1,2-benzopyrone) and 7-hydroxycoumarin on human malignant cell lines in vitro. J. Cancer Res. Clin. Oncol. 1994, 120, S3-S10.

37. Maucher, A.; Vonangerer, E. Antitumour activity of coumarin and 7-hydroxycoumarin against 7, 12-dimethylbenz[a]anthracene-induced rat mammary carcinomas. J. Cancer Res. Clin. Oncol. 1994, 120, 502-504.

38. Hu, K.; Kobayashi, H.; Dong, A.; Iwasaki, S.; Yao, X.S. Antifungal, antimitotic and anti-HIV-1 agents from the roots of Wikstroemia indica. Planta Med. 2000, 66, 564-567.

39. Ko, F.N.; Chang, Y.L.; Kuo, Y.H.; Lin, Y.L.; Teng, C.M. Daphnoretin, a new protein kinase C activator isolated from Wikstroemia indica C.A. Mey. Biochem. J. 1993, 295, 321-327.

40. Wang, J.P.; Raung, S.L.; Kuo, Y.H.; Teng, C.M. Daphnoretin-induced respiratory burst in rat neutrophils is, probably, mainly through protein kinase C activation. Eur. J. Pharmacol. Mol. Pharmacol. Sect. 1995, 288, 341-348.

41. Chen, H.C.; Chou, C.K.; Kuo, Y.H.; Yeh, S.F. Identification of a protein kinase C (PKC) activator, daphnoretin, that suppresses hepatitis B virus gene expression in human hepatoma cells. Biochem. Pharmacol. 1996, 52, 1025-1032.

42. Ho, W.S.; Xue, J.Y.; Sun, S.S.M.; Ooi, V.E.C.; Li, Y.L. Antiviral Activity of Daphnoretin Isolated from Wikstroemia indica. Phytother. Res. 2010, 24, 657-661.

43. Alexander-Lindo, R.L.; Morrison, E.Y.S.A.; Nair, M.G.; McGrowder, D.A. Effect of the Fractions of the Hexane Bark Extract and Stigmast-4-en-3-one Isolated from Anacardium occidentale on Blood Glucose Tolerance Test in an Animal Model. Int. J. Pharmacol. 2007, 3, 41-47.

44. Kiyoshi, H.; Yukari, N.; Masakazu, M.; Sansei, N.; Katsuyuki, U.; Kimiko, S.; Tetsuya, K.; Akinobu, S. Antiarrhythmic agent. Japan Patent 2003-113107, 18 April 2003. 
45. Prachayasittikul, S.; Suphapong, S.; Worachartcheewan, A.; Lawung, R.; Ruchirawat, S.; Prachayasittikul, V. Bioactive Metabolites from Spilanthes acmella Murr. Molecules 2009, 14, 850-867.

46. Yang, Y.; Kinoshita, K.; Koyama, K.; Takahashi, K.; Tai, T.; Nunoura, Y.; Watanabe, K. Anti-emetic principles of Pogostemon cablin (Blanco) Benth. Phytomedicine 1999, 6, 89-93.

47. Kolak, U.; Arı, Ş.; Birman, H.; Hasançebi, S.; Ulubelen, A. Cardioactive Diterpenoids from the Roots of Salvia amplexicaulis. Planta Med. 2001, 67, 761-763.

48. Saludes, J.P.; Garson, M.J.; Franzblau, S.G.; Aguinaldo, A.M. Antitubercular constituents from the hexane fraction of Morinda citrifolia L. (Rubiaceae). Phytother. Res. 2002, 16, 683-685.

49. Tewtrakul, S.; Tansakul, P.; Daengrot, C.; Ponglimanont, C.; Karalai, C. Anti-inflammatory principles from Heritiera littoralis bark. Phytomedicine 2010, 17, 851-855.

50. Silva, M.L.; Martins, C.H.; Lucarini, R.; Sato, D.N.; Pavanb, F.R.; Freitas, N.H.; Andrade, L.N.; Pereira, A.C.; Bianco, T.N.; Vinholis, A.H.; et al. Antimycobacterial activity of natural and semi-synthetic lignans. Z. Naturforsch. C 2009, 64, 779-784.

51. Gottlieb, H.E.; Kotlyar, V.; Nudelman, A. NMR Chemical Shifts of Common Laboratory Solvents as Trace Impurities. J. Org. Chem. 1997, 62, 7512-7515.

52. The Herbarium of French Polynesia. Available online: http://www.herbier-tahiti.pf (accessed on 25 February 2013).

Sample Availability: Samples of the compounds 1-11 are available from the authors.

(C) 2013 by the authors; licensee MDPI, Basel, Switzerland. This article is an open access article distributed under the terms and conditions of the Creative Commons Attribution license (http://creativecommons.org/licenses/by/3.0/). 